\title{
Synthesis and Evaluation of Thiazolyl pyrazolin-5-one Derivatives as Antioxidants for Egyptian Lubricating Oil.
}

\author{
Ahmed A. Fadda, Ahmed El-Mekabaty, Khaled El-Saeed and Ehab Abdel-Latif* \\ Department of chemistry, Faculty of Science, Mansoura University, ET-35516 \\ Mansoura, Egypt.
}

$\mathbf{T}$ HE CHEMICAL structure of pyrazole-1-carbothioamide derivative 1 was modified through building a thiazole moiety to synthesize derivatives of thiazolyl pyrazolin-5one. The reaction of 1 with phenacyl bromide furnished the conforming thiazolyl pyrazole derivative 2, which upon base-catalyzed reaction with benzyl isothiocyanate afforded thiazolyl 4-(benzylthiocarbamoyl)-2-pyrazolin-5-one derivative 3. The diazo-coupling reaction of 2 with diazotized 4-aminoacetophenone afforded the conforming thiazolyl 4-(p-acetylphenylhydrazono)-2-pyrazolin-5-one derivative 4. The synthesized thiazolyl pyrazolin-5-one derivatives were utilized as antioxidant additives for lubricating oil. The oxidation stability study revealed that the tested compounds showed good antioxidant activities. The efficiency of the tested antioxidant additives decreases according to the order: compound 2 $>$ compound $4>$ compound $3>$ compound 1 .

Keywords: Pyrazolin-5-one, Thiazolyl-pyrazolin-5-one, Benzyl isothiocyanate, p-Aminoacetophenone, Lubricating oil, Antioxidant Additives.

Introduction

Lubricating oil is very important to provide a fluid layer separating moving surfaces and to remove heat and wear particles while keeping friction at minimum. In the internal combustion engines, Lubricants suffer from oxidation due to contact with oxygen (air) at high temperatures for long periods and are associated with metals (iron, copper, lead, etc.), used in engine manufacturing. These metals behave as catalysts for oxidation of lubricating oil and are responsible for the formation of oxygenated oil-soluble and insoluble products. For these reasons, much researches have been devoted to the development of lubricants. Previous studies have been reported that the most essential additives used with lubricating oils are pyrazole [1-6] and thiazole derivatives [7-10]. In our research, we report on the construction of three thiazolyl pyrazole compounds, their structures elucidation by spectroscopic tools (IR, ${ }^{1} \mathrm{H}$ NMR and MS) and evaluation of their efficiencies as antioxidants for the Egyptian lubricating oil.

\section{Experimental}

All melting points were determined on an electrothermal Gallenkamp apparatus (Germany).
The IR spectra were measured on a Mattson 5000 FTIR Spectrometer (USA) in potassium bromide discs. ${ }^{1} \mathrm{H}$ NMR spectra were recorded in DMSO-d $\mathrm{d}_{6}$ on a Bruker WP spectrometer (USA) (300 MHz) and the chemical shifts $\delta$ downfield from TMS as an internal standard. Elemental analyses were carried out by the Micro-analytical unit of Faculty of Science, Cairo University, Giza, Egypt.

3-Methyl-1-thiocarbamoyl-2-pyrazolin-5-one (1) has been prepared by the reaction of ethyl acetoacetate with thiosemicarbazide according to the previously reported methodology [11].

3-Methyl-1-(4-phenyl-thiazol-2-yl)-2pyrazolin-5-one (2) has been prepared by the reaction of 2-pyrazolin-5-one compound 1 with phenacyl bromide in refluxing ethanol containing drops of triethylamine [12].

4-(Benzylthiocarbamoyl)-3-methyl-1-(4phenylthiazol-2-yl)-2-pyrazolin-5-one (3). Benzyl isothiocyanate $(0.01 \mathrm{~mol}, 1.3 \mathrm{ml})$ was added into a stirred mixture of thiazolyl pyrazolone $2(0.01 \mathrm{~mol}$, $2.57 \mathrm{~g})$ and potassium hydroxide ( $0.01 \mathrm{~mol}, 0.56$ $\mathrm{g})$ in $15 \mathrm{ml}$ DMF. The reaction mixture was stirred for 8 hours, poured into ice-cooled water and then neutralized with dilute $\mathrm{HCl}$ to form precipitate.

*Corresponding author email: ehabattia00@yahoo.com

DOI: $10.21608 /$ jtcps.2019.9991.1020

(C)2019 National Information and Documentation Centre (NIDOC) 
The precipitate was collected by filtration, and recrystallized from ethanol. Red powder; yield 70\%; m.p. $163-165{ }^{\circ} \mathrm{C}$; IR $\quad\left(\bar{v} / \mathrm{cm}^{-1}\right)$ : $3419(\mathrm{NH}), 1645(\mathrm{C}=\mathrm{O}) .{ }^{1} \mathrm{H}$ NMR $\left(\mathrm{DMSO}_{-}\right)$) d/ $\mathrm{ppm}=2.80\left(\mathrm{~s}, 3 \mathrm{H}, \mathrm{CH}_{3}\right), 4.95\left(\mathrm{~d}, 2 \mathrm{H}, \mathrm{CH}_{2}\right), 7.27-$ $7.49(\mathrm{~m}, 8 \mathrm{H}, \mathrm{Ar}-\mathrm{H}), 7.83\left(\mathrm{~s}, 1 \mathrm{H}\right.$, thiazole- $\left.\mathrm{H}_{5}\right), 8.02$ (d, 2H, Ar-H), $10.87(\mathrm{~s}, 1 \mathrm{H}, \mathrm{NH})$. Analysis for $\mathrm{C}_{21} \mathrm{H}_{18} \mathrm{~N}_{4} \mathrm{OS}_{2}$ (406.52): Calcd.: C, 62.05; H, 4.46; N, 13.78; Found: C, 61.94; H, 4.54; N, 13.82 .

4-(p-Acetylphenylhydrazono)-3-methyl-1-(4phenyl-thiazol-2-yl)-2-pyrazolin-5-one (4). To cold suspension $\left(0-5^{\circ} \mathrm{C}\right)$ of $\mathrm{p}$-aminoacetophenone $(1.35 \mathrm{~g}, 0.01 \mathrm{~mol})$ in $3 \mathrm{~mL}$ concentrated $\mathrm{HCl}$, a cold solution of sodium nitrite $(0.70 \mathrm{~g}, 0.01 \mathrm{~mol})$ in $10 \mathrm{~mL}$ water was added dropwise. The freshly prepared diazonium salt was added drop by drop to a cold solution of thiazolyl pyrazolin-5-one derivative $2(1.57 \mathrm{~g}, 0.01 \mathrm{~mol})$ in pyridine $(20 \mathrm{~mL})$ over a period of 15 minutes. The reaction mixture was stirred at $\left(0-5^{\circ} \mathrm{C}\right)$ for 1 hour and then diluted with water. The precipitate that formed was filtered off, dried and recrystallized from ethanol/DMF mixture $(2: 1)$. Yellow powder, yield $=65 \%$, m.p. $=238-240^{\circ} \mathrm{C}$. IR $\left(\bar{v} / \mathrm{cm}^{-1}\right): 3118(\mathrm{NH}), 1671$ $(\mathrm{C}=\mathrm{O}) .{ }^{1} \mathrm{H}$ NMR $($ DMSO-d $): \mathrm{d} / \mathrm{ppm}=2.35(\mathrm{~s}, 3 \mathrm{H}$, $\left.\mathrm{CH}_{3}\right), 2.55\left(\mathrm{~s}, 3 \mathrm{H}, \mathrm{CH}_{3}\right), 7.31-8.03(\mathrm{~m}, 10 \mathrm{H}, \mathrm{Ar}-\mathrm{H}$ and thiazole- $\left.\mathrm{H}_{5}\right), 13.04(\mathrm{~s}, 1 \mathrm{H}, \mathrm{NH})$. Analysis for $\mathrm{C}_{21} \mathrm{H}_{17} \mathrm{~N}_{5} \mathrm{O}_{2} \mathrm{~S}$ (403.46): Calcd.: C, 62.52; H, 4.25; N, 17.36; Found: C, 62.70; H, 4.21; N, 17.26.

\section{Results and Discussion}

Synthesis of thiazolyl-pyrazolone compounds 2 , 3 and 4 . The targeted thiazolyl pyrazole compounds were constructed according to the synthetic strategies that depicted in Scheme (1). Pyrazole-1carbothioamide derivative 1 [11] was utilized as a building block for the construction of three thiazolylpyrazolone derivatives 2,3 and 4 . The reaction of 1 with phenacyl bromide to give 3-methyl-1-(4phenyl-thiazol-2-yl)-2-pyrazolin-5-one (2) has been achieved by heating in ethyl alcohol containing three drops of triethylamine [12].

The base-catalyzed reaction of thiazolylpyrazolone derivative 2 with benzyl isothiocyanate in dry DMF in the presence of $\mathrm{KOH}$ followed by treatment with dilute hydrochloric acid furnished the conforming thiocarbamoyl derivative 3 . The suggested chemical structure of 3 has been assigned based on the convenient spectral data. The infrared spectrum showed absorptions at 3419 and $1645 \mathrm{~cm}^{-1}$ for the $(\mathrm{NH})$ and $(\mathrm{C}=\mathrm{O})$ groups, respectively. Its ${ }^{1} \mathrm{H}$ NMR spectrum displayed singlet signal at $2.80 \mathrm{ppm}$ for three protons $\left(\mathrm{CH}_{3}\right)$, doublet at $4.95 \mathrm{ppm}$ for two protons $\left(\mathrm{CH}_{2}\right)$, multiplet in the region 7.27-7.49 ppm due to eight aromatic protons, singlet at 7.83 $\mathrm{ppm}$ indicating the proton of thiazole- $\mathrm{C}_{5}$, doublet for two aromatic protons at $8.02 \mathrm{ppm}$ and triplet at $10.87 \mathrm{ppm}$ due to the proton of imino group (NH).

Thiazolyl-pyrazolone derivative 2 underwent electrophilic diazo-coupling of with diazotized p-aminoacetophenone in pyridine at $0-5^{\circ} \mathrm{C}$ afforded the corresponding thiazolyl 4-arylhyrazonopyrazolone derivative 4 . The chemical structure of 4 was verified based on convenient spectral analyses. The infrared spectrum exhibited absorptions at 3118 and $1671 \mathrm{~cm}^{-1}$ for the $(\mathrm{NH})$ and $(\mathrm{C}=\mathrm{O})$ groups. Its ${ }^{1} \mathrm{H}$ NMR spectrum in DMSO-d $\mathrm{d}_{6}$ displayed two singlet signals at 2.35 and $2.55 \mathrm{ppm}$ (two $-\mathrm{CH}_{3}$ groups), multiplet in the region 7.31-8.03 ppm for the aromatic and thiazole- $\mathrm{C}_{5}$ protons and singlet at $13.04 \mathrm{ppm}$ for the proton of $\mathrm{NH}$ group.<smiles>CCOCCNC(=O)CCC(=O)OCC</smiles>

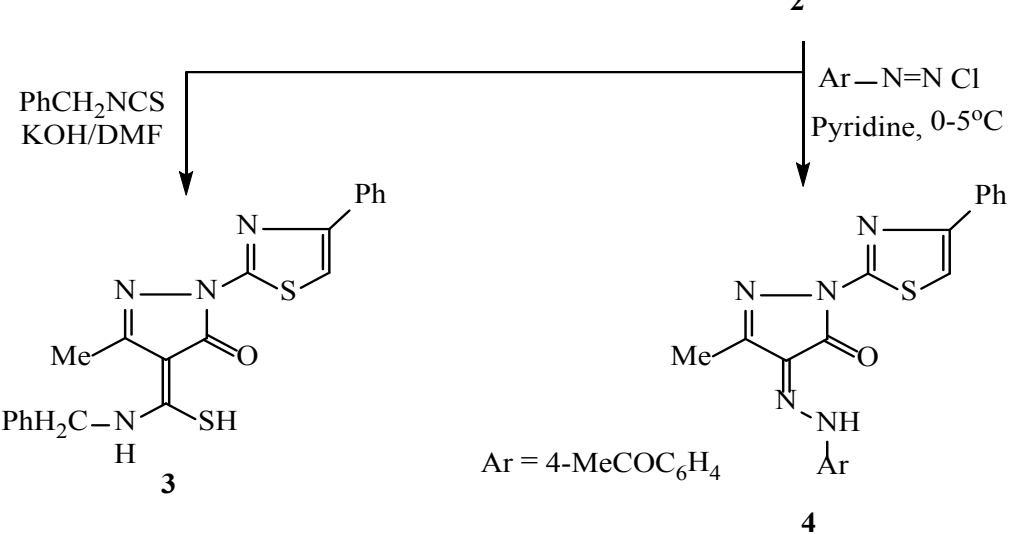

Scheme 1. Synthesis of thiazolyl-pyrazolone derivatives 2,3 and 4. 
Thiazolyl-pyrazolones as antioxidant additives. The synthesized thiazolyl pyrazolin-5one compounds 1, 2, 3 and 4 were evaluated as antioxidants for lubricating oil. The effectiveness of the synthesized compounds as antioxidants were verified according to the previously reported method [13].

Samples were withdrawn at regular intervals (each three hours), and examined for their oxidation stability, which expressed in terms of the total acid number (TAN) and then compared them with the lubricating oil sample without additives.

The empirical data (Table 1) graphically presented in Figure 1 provides an overview of the efficacy of antioxidant additives in controlling oxidation reactions compared to oil without antioxidant additives. In the absence of additives, oxidation products have increased over time. When the prepared compounds (1, 2, 3 and 4) were added to the used oils, the oxidation products also increased over time but at a much lower rate than those without additives.

Table (1) and Figure (1) indicated that, T.A.N. displayed good oxidation resistances to the tested oil. Compound 2 exhibited the highest antioxidant activity. The obtained T.A.N. values showed that the oxidation inhibition efficiency of the four compounds follows the sequence: compound $2>$ compound $4>$ compound $3>$ compound 1 compared with blank sample.

It was also useful to compare the oxidation stability of the tested lubricants containing the prepared antioxidants $(0.1 \mathrm{~g} / \mathrm{L})$ with the lubricant oil containing a commercial antioxidant supplement purchased from the local market (Misr super $7500,20 \mathrm{w} / 50$ hours). The results after 36 hours oxidation at $155^{\circ} \mathrm{C}$ with air at a rate 5 liter/ hour as shown in Table (2) and Figure (2) illustrates that, lubricating oil containing these compounds $(1,2,3$ and/or 4) showed better stability for oxidation than commercial lubricant oil tested.

The highest antioxidant activity of the tested compounds 1, 2, 3 and 4 could be attributed to the extensive conjugation, which share in the stabilization of the free radical. Furthermore, it has reasonable speculation that the introduction of amino and thiol groups in compounds 1 and 3 , would lead to stability of the formed radicals.

TABLE 1. Variation of T. A. N. with oxidation time of the tested lube oil samples without and with additives $(1,2$, 3 and 4$)$.

\begin{tabular}{|c|c|c|c|c|c|c|c|c|c|c|c|c|}
\hline \multirow{2}{*}{ Cpd. No. } & \multicolumn{12}{|c|}{ Time (hours) } \\
\hline & 3 & 6 & 9 & 12 & 15 & 18 & 21 & 24 & 27 & 30 & 33 & 36 \\
\hline OWA & 4.9 & 5.5 & 6.1 & 6.6 & 7.2 & 7.8 & 8.4 & 8.9 & 9.5 & 9.9 & 10.5 & 11.7 \\
\hline 1 & 2.2 & 2.4 & 2.8 & 3.2 & 3.5 & 3.9 & 4.2 & 4.5 & 4.8 & 5.2 & 5.5 & 5.8 \\
\hline 2 & 0.6 & 0.8 & 0.9 & 1.1 & 1.3 & 1.5 & 1.8 & 2.2 & 2.5 & 2.8 & 3.2 & 3.4 \\
\hline 3 & 1.1 & 1.4 & 1.6 & 1.8 & 2.0 & 2.2 & 2.5 & 2.9 & 3.0 & 3.4 & 3.7 & 4.0 \\
\hline 4 & 0.8 & 1.1 & 1.2 & 1.4 & 1.6 & 1.8 & 2.1 & 2.5 & 2.8 & 3.0 & 3.4 & 3.6 \\
\hline
\end{tabular}

OWA $=$ Oil Without Additives

TABLE 2. T.A.N. values of the examined lubricating oil samples ontaining $0.1 \mathrm{~g} /$ liter of antioxidants $(1,2,3$ and/ or 4) against the commercial oil.

\begin{tabular}{|c|c|c|c|c|c|c|c|c|c|c|c|c|}
\hline \multirow{2}{*}{$\begin{array}{l}\text { Cpd. } \\
\text { No. }\end{array}$} & \multicolumn{12}{|c|}{ Time (hours) } \\
\hline & 3 & 6 & 9 & 12 & 15 & 18 & 21 & 24 & 27 & 30 & 33 & 36 \\
\hline OWA & 4.9 & 5.5 & 6.1 & 6.6 & 7.2 & 7.8 & 8.4 & 8.9 & 9.5 & 9.9 & 10.5 & 11.7 \\
\hline $\mathrm{CO}$ & 3.1 & 3.5 & 3.9 & 4.4 & 4.9 & 5.2 & 5.6 & 5.97 & 6.4 & 6.8 & 7.1 & 7.2 \\
\hline 1 & 2.2 & 2.4 & 2.8 & 3.2 & 3.5 & 3.9 & 4.2 & 4.5 & 4.8 & 5.2 & 5.5 & 5.8 \\
\hline 2 & 0.6 & 0.8 & 0.9 & 1.1 & 1.3 & 1.5 & 1.8 & 2.2 & 2.5 & 2.8 & 3.2 & 3.4 \\
\hline 3 & 1.1 & 1.4 & 1.6 & 1.8 & 2.0 & 2.2 & 2.5 & 2.9 & 3.0 & 3.4 & 3.7 & 4.0 \\
\hline 4 & 0.8 & 1.1 & 1.2 & 1.4 & 1.6 & 1.8 & 2.1 & 2.5 & 2.8 & 3.0 & 3.4 & 3.6 \\
\hline
\end{tabular}




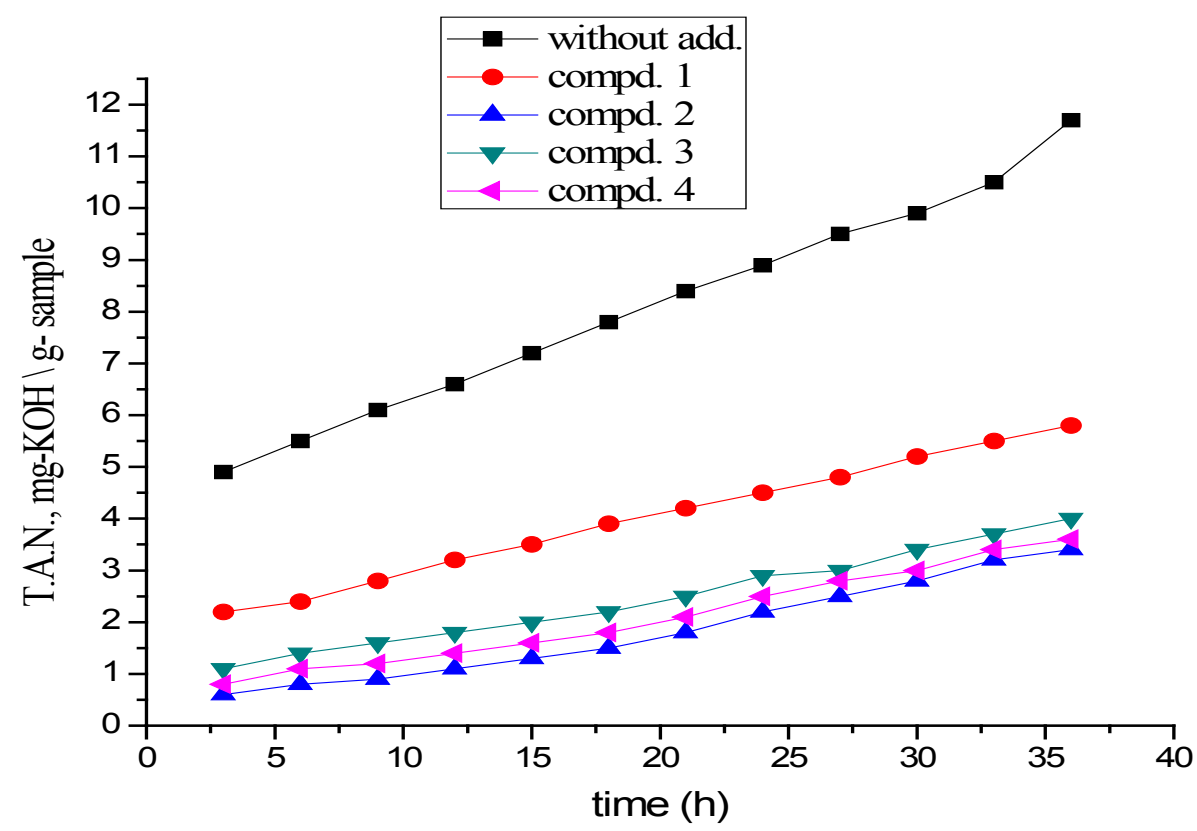

Fig. 1. Variation of T.A.N. with oxidation time of tested lubricating oil without and with compounds $1,2,3$ and 4.

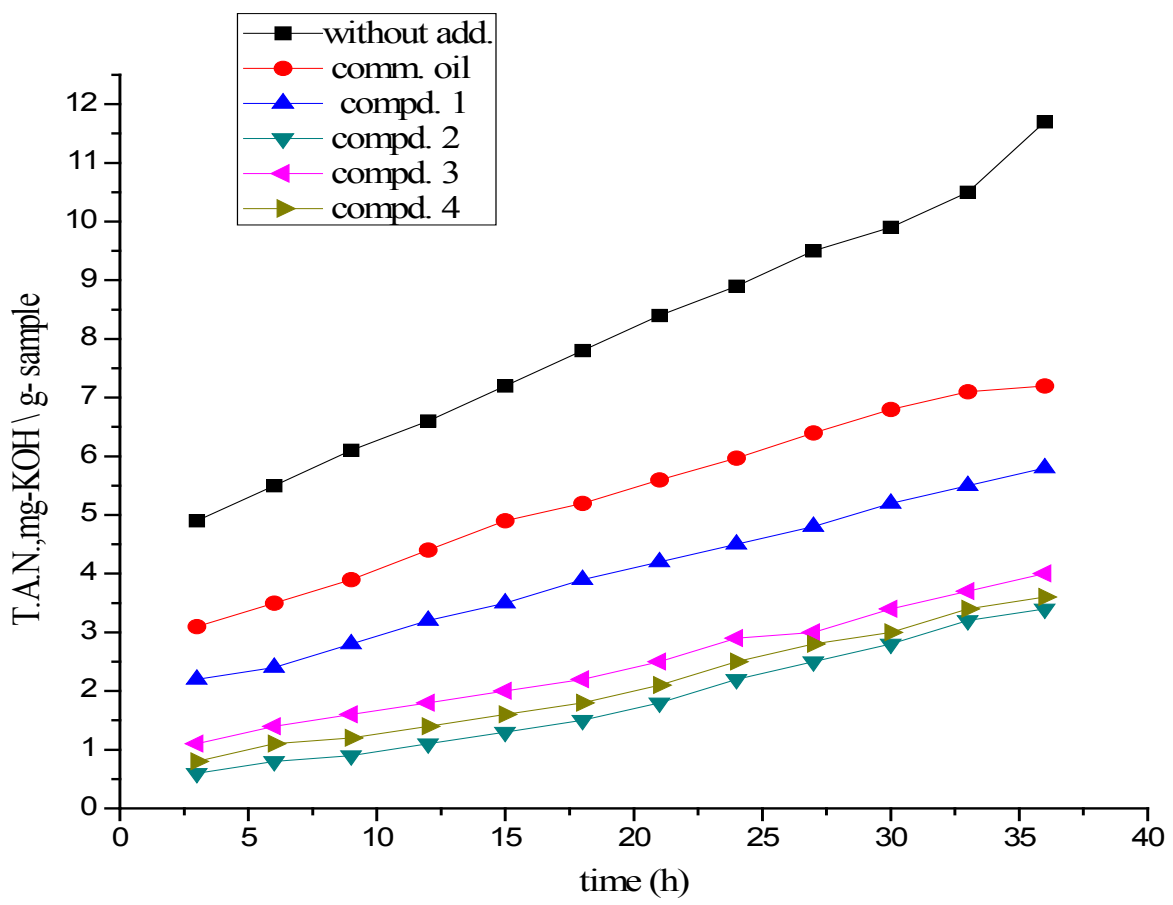

Fig. 2. T.A.N. values of the examined lubricating oil samples containing $0.1 \mathrm{~g} /$ liter of antioxidants $1,2,3$ and/or 4 against the commercial oil at $155^{\circ} \mathrm{C}$.

J. Text. Color. Polym. Sci. 16, No. 1 (2019) 


\section{Conclusion}

Different thiazolyl 2-pyrazolin-5-one derivatives 1-4 were synthesized (IR, ${ }^{1} \mathrm{H}$ NMR and MS confirmed their assumed structures) and applied as antioxidants additives for lubricating oils.

\section{Research Highlights}

- Synthesis of some new thiazolyl 2-pyrazolin-5one derivatives.

- Their characterization by IR and $1 \mathrm{H}$ NMR spectroscopic techniques.

- Their application as antioxidant additives for lubricating oils.

\section{References}

1. Fikry, R. M., El-Adly, R. A., Ismail, N. A., El-Tabie, A. S., Al-Aidy, H. Some azine and azole derivatives as antioxidant additives for lithium lubricating grease. Egypt. J. Pet. 22, 61-71 (2013).

2. Hassan, H. M., Habib, O. M. O., Moawad, E. B., El-Bana, G. G. Synthesis and Evaluation of Some New Quinazolinone Derivatives as Antioxidant and Anticorrosive Additives for Egyptian Gasoline Motor Oils. Inter. J. Modern Org. Chem. 1, 150-164 (2012).

3. Ahmad, M. R., Mohammed, A. A.-K., Ali, Y., Al-Messri, Z. A. K. Synthesis, Characterization and Evaluation of Some Pyranopyrazoles and Pyranopyrimidines Derivatives as Antioxidants for Lubricating Oils. Iraqi J. Sci. 55, 1-11 (2014).

4. Hassan, H. M., Habib, O. M. O., Moawad, E. B., El-Bana, G. G., El Defrawy, A. M. Synthesis of some novel antioxidant and anticorrosive additives for Egyptian gasoline motor oils. Lubrication Sci. 23, 119-138 (2011).

5. El-Mekabaty, A., Habib, O. M. O. Synthesis and evaluation of some novel additives as antioxidants and corrosion inhibitors for petroleum fractions. Pet. Sci., 11, 161-173 (2014).

6. El-Ashry, E. H., El-Rafi, M. E., Elnagdi, M. H., Abou-Elnaga, H. H., Abdel Azim, W. M. A., Boghdadi, Y. M. Antioxidant additives for lubricating oils. Synthesis and evaluation of some polyfunctionalized phenols linked to heterocycles. Jordan J. Chem. 4, 221-231 (2009).

7. Amer, F. A., Hassan, H. M., Moawad, E. B., Shaker, N. Synthesis and evaluation of some new thiazoles as antioxidant additives for Egyptian lubricating oils. Advances in Petroleum Exploration and Development 1, 40-49 (2011).
8. Abdel-Wahab, B. F., Gaffer, H. E., Fouda, M. G.,Osman, E. M.; Fahmy, H. M. Synthesis of some new 2-[(2,3-dihydroinden-1-ylidene)-hydrazinyl]4-methylthiazole derivatives for simultaneous dyeing and finishing for UV protective cotton fabrics. J. Applied Polymer Sci. 112, 2221-2228 (2009).

9. Shaaban, S., Gaffer, H. E., Alshahd, M., Elmorsy, S. S. Cytotoxic symmetrical thiazoledislenides with increased selectivity against MCF-7 breast cancer cells. International Journal of Research and Development in Pharmacy and Life Sciences 4, 1654-1668 (2015).

10. Gaffer, H. E., Abdel-Fattah, S., Etman, H. A.,Abdellatif, E. Synthesis and antioxidant activity of some new thiazolylpyrazolone derivatives. J. Heterocycl. Chem. 54, 331-340 (2017).

11. Harode, R., Sharma, T. C. Synthesis of 2-(3methylpyrazol- 5-one-1-yl)-4-arylthiazoles. $J$. Indian Chem. Soc. 66, 282-284 (1989).

12. Bondock, S., El-Azap, H., Kandeel, E.-E. M., Metwally, M. A. Eco-friendly solvent-free synthesis of thiazolylpyrazole derivatives. Monatsh. Chem. 139, 1329-1335 (2008).

13. Sidney S. Quantitative Organic Chemistry (3rd edn), Jolu Willey and Sons Inc, New York: 130-133

(Received 24 / 2 /2019; accepted $12 / 3 / 2019$ ) 


\section{تخليق وتقييم مشتقات ثيازوليل بيرازولينون كمضادات أكسدة لزيت التشحيم المصري

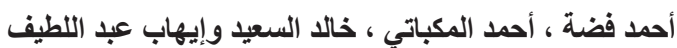

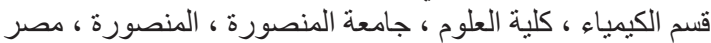

يتضمن البحث تحضير استخدام مشتق بير ازول1--كاربوثيو أميد (1) في تحضير مشتقات ثيازوليل بير ازولين-

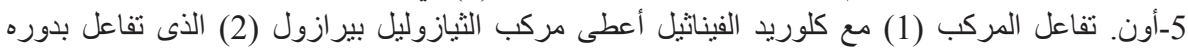

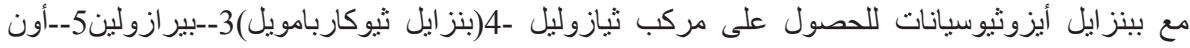

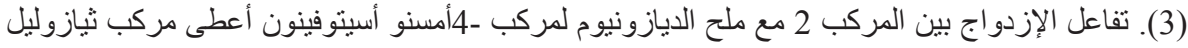

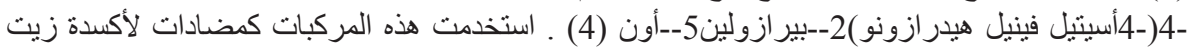

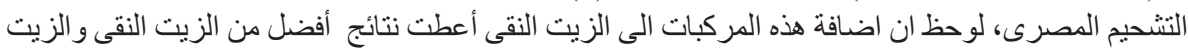

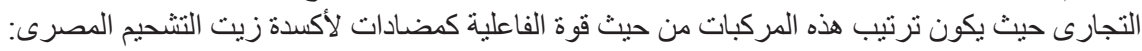
المركب 2 > المركب 4 > المركب 3 > المركب الت من حنب 1. 